SLOVO, sv. 71 (2021), 57-76, Zagreb 2020.

Kristijan KUHAR

UDK $272-528$

Staroslavenski institut

272-282.7:003.349.1

Zagreb

kristijan.kuhar@stin.hr

Izvorni znanstveni članak

Primljen: 10. kolovoza 2020.

Prihvaćen: 20. listopada 2020.

\title{
O SADRŽAJU DRUGOGA BERAMSKOG BREVIJARA
}

\begin{abstract}
Hrvatskoglagoljski brevijari sadrže obiman korpus biblijskih i liturgijskih tekstova koji su prepisivanjem (i kasnije tiskom) prenošeni iz jednoga u drugi brevijarski kodeks od 13. stoljeća do 1561. godine. Istraživanje je hrvatskoglagoljskih brevijarskih tekstova tijekom 20. stoljeća donijelo vrijedne rezultate u području povijesti jezika, transmisije tekstova i njihove povezanosti te paleografije. Znanstvenim centrom izvrsnosti za hrvatsko glagoljaštvo istraživanjima se hrvatskoglagoljskoga brevijara pristupilo i sa stajališta raščlambe njegova liturgijskog sadržaja. Ovim se radom donosi pregled dosadašnjih istraživanja te poticaji koje različiti autori iznose u pogledu smjerova suvremenih i budućih liturgijskih istraživanja. U središnjem se dijelu rada iznose rezultati proučavanja strukture i sadržaja Drugoga beramskog brevijara koji mogu utjecati na oblikovanje kriterija i za istraživanje drugih hrvatskoglagoljskih brevijara.
\end{abstract}

Ključne riječi: glagoljaštvo, brevijar, Drugi beramski brevijar, povijest liturgije

\section{HRVATSKOGLAGOLJSKI BREVIJARI I NJIHOV SADRŽAJ}

Liturgijske knjige pisane i tiskane glagoljicom na hrvatskome crkvenoslavenskom jeziku sadrže bogatu tradiciju koja potječe iz 9. stoljeća te se u kontinuitetu održala na hrvatskim prostorima do 20. stoljeća. Vrijedna filološka, povijesna i književna istraživanja koja se objedinjuju u paleoslavistici otkrila su i obradila na desetke cjelovitih rukopisa zapadne, rimske liturgijske tradicije koja se očuvala na prostorima istočnog Jadrana, te sporadično i u središnjoj Hrvatskoj. Govorimo li o liturgijskim rukopisima pisanim glagoljicom i hrvatskim crkvenoslavenskim jezikom, redovito se zaključuje da je riječ o misalima i brevijarima koji se tipološki mogu usporediti s latinskim misalima i brevijarima rimskoga obreda. I nakon otkrića tiska, koje je bilo vezano uz la- 
tinski jezik, pisari glagoljaši prihvaćaju tada suvremene tekovine, te priređuju za tisak liturgijske knjige pisane glagoljicom i hrvatskim crkvenoslavenskim jezikom. Tekstualni sadržaj hrvatskoglagoljskih misala i brevijara, kao i zbirki homilija te teoloških testova u zbornicima, Josip Leonard Tandarić nazvao je hrvatskoglagoljska liturgijska književnost, ${ }^{1}$ čime je naznačio da je u temelju hrvatske književnosti pisane glagoljicom i crkvenoslavenskim jezikom upravo liturgija - bogoslužje, kao izraz crkvenosti, duhovnosti i kulture.

Među rukopisnim i tiskanim liturgijskim knjigama rimskoga obreda posebno se ističu svojim bogatim liturgijskim i svetopisamskim sadržajem hrvatskoglagoljski brevijari. Do 21. stoljeća obrađeno je tridesetak hrvatskoglagoljskih brevijara koji se mogu okarakterizirati kao cjeloviti kodeksi. Njihova datacija obaseže razdoblje od 13. stoljeća, vremena sačuvanih fragmenata (usp. PANTELIĆ 1993), pa do 1561. godine kada je u Veneciji tiskan Brozićev brevijar. Sadržaj hrvatskoglagoljskih cjelovito sačuvanih brevijara je raznolik. Iako ne postoje dva identična hrvatskoglagoljska brevijara, ipak se na razini cjelokupnog korpusa tih liturgijskih knjiga prepoznaju cjeline brevijarskog teksta: Proprium de tempore, Proprium i Commune sanctorum. U nekima je uz brevijarski tekst sadržan i tekst za razne obrede i svetu misu. Od brojnih su hrvatskoglagoljskih brevijara sačuvane samo pojedine cjeline liturgijskih tekstova. U popisu brevijara naznačena su svojstva njegova sadržaja. Cjelovit brevijar sadrži tekstove liturgijskih cjelina Proprium de tempore i Proprium sancotorum te Commune sanctorum. Nedostaje li određenom primjerku brevijara neki od netom navedenih cjelina liturgijskih tekstova, ili su i pojedine cjeline nepotpune, pridaje se naziv one liturgijske cjeline koju sadrži. U nastavku slijedi popis hrvatskoglagoljskih brevijara ${ }^{2}$ s naznakom cjelina koje određeni primjerak sadrži:

13./14. st. Prvi vrbnički brevijar; Proprium de tempore

14. st. Vatikanski brevijar Borg. Illirico 5, 1. dio; Proprium de tempore

Vatikanski brevijar Borg. Illirico 6, 2. dio; Proprium i Commune sanctorum

14. st. $\quad$ Oxfordski misal-brevijar; Proprium de tempore i Proprium sanctorum

1 Tandarić dijeli glagoljsku religioznu književnost na liturgijsku i izvanliturgijsku književnost. Usp. TANDARIĆ 1993: 16.

2 Digitalne se snimke hrvatskoglagoljskih brevijara s popisa, objedinjene u intranetsku digitalnu bazu »Izvori« (izvori.stin.hr), dostupne na mrežnim stranicama Staroslavenskog instituta. Bazu su uredile Marica Čunčić i Ljiljana Mokrović. 
14. st. Drugi vrbnički brevijar; Proprium de tempore

14. st. Četvrti vrbnički brevijar; Proprium sanctorum i Commune sanctorum

14. st. $\quad$ Padovanski brevijar; Proprium de tempore

kraj 14. st. Prvi beramski brevijar; Proprium sanctorum

1396. g. $\quad$ Brevijar Vida Omišljanina; Proprium de tempore

14.-15. st. Pašmanski brevijar; Proprium de tempore, Proprium i Commune sanctorum

1442. g. $\quad$ Brevijar Metropolitanske knjižnice; Proprium de tempore i Proprium sanctorum

1407. g. $\quad$ Dragućki brevijar; Proprium de tempore

1442.-1443.g. Moskovski brevijar, 1. i 2. dio; Proprium de tempore, Proprium i Commune sanctorum

1459. g. $\quad$ Prvi novljanski brevijar; Proprium de tempore, Proprium i Commune sanctorum

1460. g. Brevijar popa Mavra; Proprium de tempore, Proprium i Commune sanctorum

1465. g. Vatikanski 19, Vat. Slav. 19; Proprium de tempore, Proprium i Commune sanctorum

1470. g. Bribirski brevijar; Proprium de tempore, Proprium i Commune sanctorum

1485. g. Kukuljevićev (Vinodolski) brevijar; Proprium de tempore, Proprium i Commune sanctorum

1485. g. Vatikanski 10 (Borg. Illirico 10); Proprium de tempore, Proprium i Commune sanctorum

1486. g. Dabarski brevijar; Proprium de tempore, Proprium i Commune sanctorum

1491. g. Prvotisak brevijara; Proprium de tempore, Proprium i Commune sanctorum

1493. g. Baromićev brevijar; Proprium de tempore, Proprium i Commune sanctorum

1495. g. $\quad$ Drugi novljanski brevijar; Proprium de tempore, Proprium i Commune sanctorum

15. st. Rimski brevijar; Proprium de tempore, Proprium i Commune sanctorum

15. st. Humski brevijar; Proprium sanctorum

15. st. Drugi beramski brevijar, 1. i 2. dio; Proprium de tempore, Proprium sanctorum 
15. st. Ljubljanski misal-brevijar; Commune sanctorum

15. st. Brevijar Britanske knjižnice; Proprium de tempore

15. st. Treći vrbnički brevijar; Proprium de tempore

1561. g. Brozićev brevijar; Proprium de tempore, Proprium i Commune sanctorum

1648. g. Levakovićev brevijar; Proprium de tempore, Proprium i Commune sanctorum

Iz popisa je sačuvanih hrvatskoglagoljskih brevijara uočljivo da postoji veliki broj cjelovitih brevijara, tj. onih koji sadrže sve liturgijske cjeline izvorno latinskih brevijara koji su tipološki označeni kao Breviarium secundum morem (consuetudinem) s. Romanae Curiae, ${ }^{3} \mathrm{tj}$. brevijari rimskoga obreda ili rimske kurije, a koji se u literaturi ponekad nazivaju i »franjevačkim « brevijarima jer se posredovanjem franjevačkog reda taj tip brevijara širio zapadnom rimskom Crkvom da bi nakon Tridentskog sabora bio uveden na čitavom tom području. Navedeni se latinski naziv u incipitima hrvatskoglagoljskih brevijara pojavljuje u prijevodu na hrvatski crkvenoslavenski jezik zbog čega se govori i o brevijarima »po zakonu rimskoga dvora«.

Iako svi hrvatskoglagoljski brevijari pripadaju upravo navedenome tipu, svaki primjerak hrvatskoglagoljskog brevijara ima i vlastitosti vezane za okolnosti područja u kojem je brevijar nastao kao i crkvenih potreba glagoljaškog klera koji se određenim primjerkom služi. Kao što je slučaj sa svim hrvatskoglagoljskim liturgijskim rukopisima i tiskanim knjigama, i lokalne se razlike primjeraka hrvatskoglagoljskih brevijara očituju u katalogu svetačkih imena u kalendaru i sanktoralu, a pored toga i u jeziku, načinu pisanja i iluminiranja. Ovisno o potrebama konkretnoga klera, primjerci hrvatskoglagoljskih brevijara sadrže, pored brevijarskih tekstova, tekstove za misu i neke obrede koji su sastavni dio njihova pastoralnoga djelovanja. Zbog navedenoga, ne postoje dva istovjetna primjerka hrvatskoglagoljskog brevijara (kao ni drugoga liturgijskog kodeksa), nego je svaki od njih odraz kulturnoga i duhovnoga ozračja u kojemu je nastao i u kojemu je korišten. ${ }^{4}$

Zadatak je ovoga rada utvrditi osnovna strukturna svojstva sadržaja Drugoga beramskog brevijara $\left(\mathrm{BrBer}_{2}\right)$, prepoznati njegov odnos prema latinskim brevijarima i njegovo mjesto u okviru hrvatskoglagoljskih brevijara te prepoznati barem glavne njegove strukturne posebnosti. Istraživanje se provodi metodom strukturne

3 O stvaranju ove tipologije liturgijske knjige vidi CATELLA 1994: 125-134; 2012: 295-305; KUNZLER 2003: 459-467; TAFT 1993: 307-310.

4 Usp. PANTELIĆ 1971; 1976. 
raščlambe, koju je u liturgijsku znanost uveo Robert Taft, ${ }^{5}$ a ovdje je prilagođena potrebama istraživanja hrvatskoglagoljskog brevijara. S obzirom da je cjelokupno dosadašnje istraživanje $\mathrm{BrBer}_{2}$ usredotočeno ponajprije na njegova osnovna svojstva, za iscrpno će se poznavanje toga brevijarskoga kodeksa, kao i hrvatskoglagoljskoga brevijara uopće, trebati provesti još niz opsežnih istraživanja.

\section{1. Sadržaj liturgijske knjige »brevijar«}

Sadržaj je hrvatskoglagoljskog brevijara u načelu podudaran sa sadržajem brevijara rimskoga obreda na latinskome jeziku, a on je bogat tekstovima koji potječu iz Svetoga pisma.

Okosnica je sadržaja brevijara i osnova na kojoj je izgrađena ukupna molitva časova psaltir. Cursus, tj. raspored moljenja ili pjevanja psalama, kao i hvalospjeva iz Staroga i Novoga zavjeta u okviru časova svakog dana u liturgiji se rimskoga obreda drži načela molitve određenih pravilom sv. Benedikta, kao i tradicije molitve časova u rimskim samostanima. ${ }^{6}$ Pored toga, tu su svetopisamska čitanja (kapituli ili lekcije), kao i parafraze svetopisamskih tekstova u obliku responzorija, versa i antifona. Osim svetopisamskih tekstova, brevijari rimskoga obreda sadrže i liturgijske tekstove poput molitava, himana te hagiografskih odlomaka i tekstova koji potječu iz bogate patrističke baštine.

Brevijarski su tekstovi na osnovi sadržaja i upotrebe kojoj su namijenjeni grupirani u cjeline. Tako Proprium de tempore sadrži tekstove službe časova u dane u liturgijskoj godini. Unutar te su cjeline tekstovi raspoređeni na liturgijska vremena čiji niz započinje došašćem, nastavlja se božićnim vremenom do Bogojavljenja, korizmom, uskrsnim vremenom do Pedesetnice i završava se vremenom nakon Pedesetnice. Tekstovi namijenjeni spomendanima svetaca kroz godinu okupljeni su u cjelinu Proprium sanctorum. Spomendani svetaca koji nemaju vlastita biblijska, hagiografska i patristička čitanja, kao ni cursus antifona i responzorija, smješteni su u okviru cjeline Commune sanctorum, gdje su raspoređeni prema svetačkim naslovima: ispovjedalac, mučenik, djevica, i slično. ${ }^{7} \mathrm{U}$ skladu s tradicijom nazivlja u hrvatskoj paleoslavistici, u

5 Vidi TAFT 1984: 151-164.

6 O tome vidi TAFT 1993: 121-140; PINELL 1996: 104-108.

7 Ovakav je raspored za brevijare rimskoga dvora jedinstven za sve kodekse. Tiskani brevijar iz 1568. godine, čiji se raspored temelji na starijim brevijarima, ima ova zajednička slavlja svetaca (Commune sanctorum): Commune apostolorum, Commune unius martyris, Commune plurimorum martyrum, Commune confessoris pontificis, Commune doctorum, Commune confessorum non pontificum, Commune virginum, Commune virginum et martyrum tantum. 
nastavku se ovoga teksta Proprium de tempore naziva »temporal«, Proprium sanctorum »sanktoral«, a za Commune sanctorum koristit će se nazivak »komunal«.

Pored prethodno navedenih cjelina, brevijari rimskoga obreda sadrže i tzv. Officium B. Virginis Mariae, kao i službu za pokojne (Officium defunctorum) koji su neodvojivi dio svakoga brevijara rimskoga obreda. U zasebnom se dijelu brevijara nalaze liturgijski elementi koji su pojavljuju u molitvi časova svakog dana, a riječ je o nizu psalama; zatim nizu antifona, responzorija i versa; odlomaka biblijskih i patrističkih čitanja te molitava. ${ }^{8}$

\section{NEKA DOSADAŠNJA ISTRAŽIVANJA - ODREDNICE ZA LITURGIJSKO-POVIJESNA ISTRAŽIVANJA}

Suvremena se istraživanja hrvatskoglagoljskih brevijara i njegove povijesti, a koja se često metodološki oslanjaju na digitalnu tehnologiju, epistemološki naslanjaju na rezultate ranijih povijesno-liturgijskih istraživanja. Ovdje navodimo samo neke od ranijih studija, koje su korištene u ovome radu, posebno u okviru istraživanju Drugoga beramskog brevijara.

Početci istraživanja hrvatskoglagoljskih brevijara sežu u prva desetljeća 20. stoljeća. Među prvim je istraživačima toga područja bio Josef Vajs, ${ }^{9}$ koji je kao najstariji sačuvani hrvatskoglagoljski brevijar označio Prvi vrbnički brevijar. Vajs je sastavio i prvu opsežniju bibliografiju hrvatskoglagoljskih brevijara na temelju njihova tekstološkog sadržaja.

Navedimo kako cjelovitom razdoblju sačuvanih hrvatskoglagoljskih brevijara prethodi razdoblje fragmenata brevijara. Sačuvani fragmenti brevijara, kao i fragmenti glagoljskih misala, povezuju razdoblje razvijenoga glagoljaštva (od sredine 14. stoljeća) s ćirilometodskim razdobljem iz kojega su sačuvani tekstovi psaltira, apostola, evanđelistara i euhologija, a koji su se koristili i u službi časova. Sadržaj fragmenata hrvatskoglagoljskih brevijara upućuje na postojanje liturgijske knjige za službu časova koja se tipološki ne podudara s brevijarima rimske kurije (usp. PANTELIĆ 1993).

Za Commune sanctorum vezano je i slavlje obljetnice posvete crkve, tj. Commune dedicationis Ecclesiae. A posebnu je cjelinu tvorio tzv. časoslov Blažene Djevice Marije (Officium beatae Mariae) koji se molio na određene blagdane Blažene Djevice Marije. Usp. Breviarium romanum 2012.

8 Za pojedine liturgijske elemente vidi PINELL 1996; RIGHETTI 1969: 698-793.

9 VAJS 1910. 
Nastanak hrvatskoglagoljskog brevijara istražila je Petra Stankovska te je odredila povezanosti među brevijarima na temelju biblijskih i patrističkih čitanja (STANKOVSKA 2015). Uspoređujući izabrane brevijare zaključila je da među njima postoje razlike u homiletskim tekstovima i biblijskim čitanjima. Time je došla do zaključka da su tekstovi hrvatskoglagoljskog brevijara iz 13. stoljeća tipološki stariji i da su kao takvi (tekstualnom transmisijom) ušli u mlađe brevijare (usp. STANKOVSKA 2015: 460-461). »Ulomci starijega' tipa hrvatskoglagoljskoga brevijara i njegovi tragovi u sačuvanim kodeksima govore o jednoj jasnoj i jedinstvenoj razvojnoj liniji hrvatskoglagoljskih brevijara, potpuno osnovanoj na predlošku latinskoga brevijara « (STANKOVSKA 2015: 462). Mlađi su brevijari, oni nastali nakon 1300. godine, priređivani prema novijem ordo oficii na osnovi kojega nastaje tipologija rimskoga brevijara u skladu s kojom su prevođeni, priređivani i prepisivani svi cjelovito sačuvani brevijari hrvatskoglagoljske liturgijske tradicije.

Među dosadašnjim je istraživanjima hrvatskoglagoljskih brevijara neka potrebno istaknuti. Leonard Tandarić je naznačio strukture i bibliografije sadržaja rukopisnih i tiskanih hrvatskoglagoljskih brevijara. ${ }^{10}$ Marija Pantelić svoja je istraživanja usmjerila na historijate pojedinih rukopisnih i tiskanih brevijara, smještajući ih na osnovi prepoznatih posebnosti u njihov povijesni i povijesno-liturgijski kontekst. Navedenim istraživanjima svakako treba dodati i radove Biserke Grabar, ${ }^{11}$ kao i stranih istraživača poput Vševlada Jozefa Gajdoša, ${ }^{12}$ Petre Stankovske ${ }^{13}$ i Catherine Mary MacRobert ${ }^{14}$ koji se bave tekstološkim i filološkim istraživanjima, uključujući usporedbu hrvatskoglagoljskih brevijarskih tekstova s latinskim brevijarskim tekstovima iz istoga razdoblja s ciljem što točnijeg smještaja hrvatskoglagoljskih liturgijskih kodeksa u kontekst vremena u kojem nastaju. U Staroslavenskome je institutu 2014. godine, u okviru Znanstvenog centra izvrsnosti za hrvatsko glagoljaštvo pod vodstvom Milana Mihaljevića, pokrenuto prvo cjelovito i interdisciplinarno istraživanje jednog hrvatskoglagoljskog brevijara. Naime, jedan je od glavnih predmeta istraživanja Centra Drugi beramski brevijar $\left(\right.$ BrBer $_{2}$ ) te se njegov sadržaj, jezik i povijest promatraju sa stajališta filologije i jezikoslovlja, povijesti i liturgike te paleogra-

${ }^{10}$ TANDARIĆ 1977; 1984. Tandarić ima poseban znanstveni pristup kojim prvo seže za analizom strukture čitavoga kodeksa, a potom i za pojedinim dijelovima. Ovakav metodološki pristup temelj je i suvremenih znanstvenih istraživanja liturgijskih rukopisa.

11 GRABAR 1984.

${ }^{12}$ GAJDOŠ 1966.

${ }^{13}$ STANKOVSKA 2008; 2017.

${ }^{14}$ MACROBERT 2020. 
fije. Ovdje se iznose zapažanja vezana za sadržaj tog brevijara te se ukazuje na njegove vlastitosti kao i pripadnost tipologiji brevijara rimske kurije.

\section{DRUGI BERAMSKI BREVIJAR $\left(\mathrm{BrBer}_{2}\right)$}

\subsection{Tipologija}

Drugi beramski (ili ljubljanski) brevijar, hrvatskoglagoljski je rukopis iz 15. stoljeća. Čuva se u Nacionalnoj i sveučilišnoj knjižnici (NUK) u Ljubljani pod signaturom $M s$ 163. ${ }^{15}$ Brevijar je sastavljen od dva dijela: temporal u prvome svesku (264 folija) i sanktoral u drugome svesku (176 folija).

Prvi svezak, tj. temporal, $\mathrm{BrBer}_{2}$ započinje riječima: v' ime božie $i$ svete marie · amenb · početie br'v'êla po zakonu rim'skago dvora i blaženô̂ apustolu petra i pavla ${ }^{16}$ (f. 1a) koje ujedno otkrivaju njegovu tipološku provenijenciju brevijara rimskoga obreda. U sadržaju, tj. rasporedu molitvi časova (a koji se u kasnijim latinskim brevijarima nalazi pod naslovom Rubricae generales, također evocira rimsku provenijenciju: skazb ot čina po zakonb rimbski (f. 261d-264v). Vezano za sintagmu »blaženoû apustolu petra i pavla« valja upozoriti na povezanost hrvatskoglagoljskih brevijara nastalih u i nakon 13 . stoljeća s brevijarima iz ranijeg razdoblja koji su glagoljskim pisarima služili kao predlošci i iz kojih su, vođeni pisarskim žarom, u novije brevijare mogli unijeti naslove koje su našli u tim starijim brevijarima. U slučaju BrBer ${ }_{2}$ taj je stariji predložak vjerojatno bio prijevod rimskoga monaškog brevijara. ${ }^{17}$ Da bismo provjerili tu pretpostavku potrebno je napraviti detaljniju analizu euholoških tekstova i himana.

Tekst drugoga sveska $\mathrm{BrBer}_{2}$, a koji sadrži sanktoral, počinje izrijekom: početie služabb ot svetacb po v'se leto po zakon' rim'ski (f. 1a) čime se još jednom potvrđuje da on pripada tipu rimskoga brevijara (hcsl. zakon' za lat. consuetudo). U sanktoralu je sadržan 171 sanktorem, tj. služba u čast pojedi-

${ }^{15}$ Poznata su dva beramska brevijara i dva beramska misala, a nazvani su po Bermu, mjestu svog nastanka. Čuvaju se u Narodnoj i sveučilišnoj knjižnici u Ljubljani (zbog čega se nazivaju i ljubljanskim) pod signaturama: Ms 161 (Prvi beramski brevijar), Ms 163 (Drugi beramski brevijar), Ms 162 (Prvi beramski misal) i Ms 164 (Drugi beramski misal).

${ }^{16}$ Sličnim riječima započinje temporal Baromićeva tiskanog brevijara iz 1493. godine, na $\mathrm{f}$. 73r, ali dodaje »i crskve blaženihь apostolı Petra i Pavla«. Usp. GRABAR 1984: 173. Isto tako započinje i Vat. Slav. 19. Usp. JAPUNDŽIĆ 1955: 161.

17 Japundžić tvrdi da se radi o naslovu bez pravog značenja. JAPUNDŽIĆ 1955: 187. 
nih svetaca unutar godine, počevši od mjeseca studenoga. Zamjetljivo je da BrBer $_{2}$ sadrži više »slojeva« slavlja svetaca: svece rimske Crkve (ponajviše mučenike), svece koji se časte u Italiji i svece koji su dio lokalnih ili redovničkih tradicija. Duže liturgijske službe imaju franjevački sveci, poput svete Klare (f. 110d), svetoga Antuna Padovanskog (f. 60c), svetog Franje Asiškog (f. 151a). I popis slavlja svetaca iz sanktorala $\mathrm{BrBer}_{2}$ potvrđuje pripadnost tog primjerka tipologiji rimskoga brevijara i upućuje na to da mu je predložak bio brevijar na latinskom jeziku.

Iako $\mathrm{BrBer}_{2}$ ne sadrži kalendar, na osnovi sanktorala moguće je sastaviti kalendarski katalog svetaca. BrBer $_{2}$ ne sadrži ni komunal, zbog čega se uvrštava u nepotpune brevijare, pa se pretpostavlja da je postojao zasebni svezak tog primjerka brevijara sa službama časova za svetačke blagdane kojih nema u sanktoralu.

\subsection{Analiza sadržaja BrBer $_{2}$}

Prvi svezak BrBer ${ }_{2}$ ima sve liturgijske sadržaje koji se očekuju u temporalu brevijara po zakonu rimskoga dvora. ${ }^{18}$ Njihov raspored slijedi liturgijsku godinu koja započinje subotom uoči prve nedjelje došašća, a završava XXIV. nedjeljom nakon Pedesetnice. Međutim, on ne sadrži psaltir, nego na više mjesta stoji uputa: psalmi ici $v$ saltiri (f. 105b), ${ }^{19}$ dok se od samih psalama navode samo incipiti. ${ }^{20}$ Tako na f. 1a stoji: psalmb. blagoslovlenb gospodb bogb moi, što je incipit psalma 143 (lat. Benedictus Dominus Deus meus). Kao što je slučaj s psalmima, i biblijski se hvalospjevi samo naznačuju naslovom, a ne donosi se njihov potpun

${ }^{18} \mathrm{U}$ ovoj analizi zadržavamo se na analizi liturgijskog sadržaja i njegovom crkvenoslavenskom nazivlju. Elementi koji sastavljaju službu časova su: psaltir, antifone, responzoriji, versi, čitanja (kapituli), evanđelja, molitve i himni, te dva zaziva na početku časova.

${ }^{19}$ U primjeru na f. 70b navedeno je: s' pročimi psalmi · i antifoni i berši kako se v salbtiri udr'ži. Tako pisar ponovno navodi da se u psaltiru, kao dijelu brevijara, nalaze i drugi tekstovi, tj. antifone i versi.

${ }^{20}$ Pitanje psaltira u hrvatskoglagoljskim brevijarima obradila je Mary MacRobert. Psaltir je srž svakoga brevijara, a nedostatak psaltira u korpusu liturgijskih tekstova brevijara može upućivati na dva zaključka: da je postojao neki drugi svezak sa psaltirom, ili da se navođenjem samo incipita psalma pozivalo na - poznato u srednjem vijeku - mnemotehničko sredstvo učenja psalama napamet. U primjeru Ms. Canon. Liturg. 172, MacRobert zaključuje: »Takav odnos prema psaltiru jasno se zasniva na pretpostavci da korisnik zna većinu psalama napamet i da mu je potreban samo incipit da bi znao koji treba recitirati." (eng. This treatment of the psalter is clearly based on the assumption that the user would know the majority of the psalms by heart and would need only their incipits to identify which ones to recite. MACROBERT 2020: 81, prijevod K.K.) 
tekst. ${ }^{21}$ Tako se evanđeoski hvalospjev za Jutarnju bilježi samo kao blagoslovlenb (lat. Benedictus), a za Večernju službu časova veličitb (lat. Magnificat), dok se za Povečerje (lat. Completorium) ne donosi niti naslov evanđeoskog hvalospjeva nego samo psalmb · nine otpuĉeši (f. 69c, lat. Nunc dimittis). Zanimljivo je da hrvatskoglagoljski brevijari, pa tako ni $\mathrm{BrBer}_{2}$, ne donose ni notne zapise za napjeve pojedinih psalama, kako je to u latinskim brevijarima, ${ }^{22}$ premda se u sadržaju nalaze pjevani dijelovi liturgije časova, antifone, versi i responzoriji te himni.

Pisar $\mathrm{BrBer}_{2}$ za antifone navodi riječ antifonb. Uvidom u cjelokupni sadržaj antifona $\mathrm{BrBer}_{2}$, uočljivo je da pisar neke antifone donosi u cijelosti, neke skraćuje, a za neke upućuje na psaltir. Tako npr. antifonu gospodb reče ka m'nê sinb moi esi ti · azb današ rodih'te (f. 26d) donosi u cijelosti, antifonu za subotu 3. tjedna došašća blagoslovlens gospodb (f. 21a) u incipitu i dodajući da se ostatak teksta navodi u psaltiru, a npr. na f. 21a uopće ne naznačuje o kojoj je antifoni riječ nego samo navodi antifonb i psalmi iĉi $v$ psaltiri.

U službi časova onoliko je antifona koliko je psalama. Za primjer donosimo analizu službe časova Rođenja Gospodinova koja započinje Večernjom službom uoči svetkovine, na f. 26b, s naslovom navečerê rôj 'istva hrbstova. U rimskome obredu Večernja služba ima pet psalama i pet pripadajućih antifona, kapitul, himan, vers i responzorij, antifonu za Magnificat, molitvu i otpust. ${ }^{23}$ Noćna služba, ${ }^{24}$ koju pisar BrBer ${ }_{2}$ naziva ûtrna, sastoji se od tri noćnice (lat. nocturno, a započinje s bitatoriê (lat. invitatorium) sa psalmom, nakon kojega se nalazi incipit himna na Rođenje Gospodinovo Hrbste izbavitelû vsêh. Cjeloviti je tekst himna zapisan u sklopu Večernje molitve uoči Rođenja Gospodnjega (f. 26c). Nakon toga dolaze tri noćnice, kako je u rimskome obredu redovito na svetkovine i nedjelje, a o čemu će biti još riječi u nastavku teksta. Svaka noćnica ima po tri psalma i tri antifone (od kojih je svaka ispred jednog psalma) ${ }^{25}$ te tri čitanja i tri responzorija s versima (od kojih se svaki nalazi nakon jednog čitanja) (usp. f. 27a-33a).

U službi Jutarnje Rođenja Gospodnjega, koji pisar u čitavom BrBer $_{2}$ naziva matutinb, nalazi se pet psalama s pet antifona, koje pisar (kao i antifone noćnica) također donosi u cijelosti, navodeći u rubrici $k$ matutinê $i$ godinamb, tj. da je riječ o antifonama za Jutarnju službu i za »male časove«, tj. Prvi,

${ }^{21}$ Više vidi u PINELL 1996: 127-142.

${ }^{22}$ Za primjer vidi: https://www.e-codices.unifr.ch/en/sbe/0083/8v/0/Sequence-971.

${ }^{23} \mathrm{U} \mathrm{BrBer}_{2}$ nedostaje antifona za evanđeoski hvalospjev Magnificat na f. 26d. Antifone za pet psalama donesene su u cijelosti na f. $26 \mathrm{~b}$.

${ }^{24}$ O noćnim službama u srednjovjekovnoj liturgiji vidi KOŠĆAK 2020.

${ }^{25}$ Antifone i psalmi nalaze se na f. 26d-27a za prvu noćnicu, f. $28 \mathrm{~d}$ za drugu noćnicu te f. 30b-30c za treću noćnicu. 
Treći, Šesti i Deveti čas. Na kraju Jutarnje službe stoji k blagoslovlenb antifonb, tj. antifona za evanđeoski hvalospjev Benedictus (Lk 1, 68-79), slava va viš'nihb bogu · i na zemli mir'v' človêcêhb blagovoleniê (f. 33c). Večernja služba časova ima, kao i Jutarnja, pet psalama s antifonama koje su donesene u cijelosti (f. 33d) kao što je i antifona za veličitb zapisana u cijelosti. ${ }^{26}$

Među pjevanim dijelovima službe časova rimskoga obreda još su responzoriji, nizovi redaka ili parafraza redaka biblijskih čitanja ili psalama (katkad hagiografskih ili patrističkih čitanja) koje naizmjence pjevaju predmolitelj i skup ostalih molitelja. Redak koji pjeva (ili recitira) predmolitelj naziva se $\mathrm{i}$ vers (lat. versus 'redak', hcsl. beršb) ${ }^{27}$ a otpjev se ostalih molitelja i sam naziva responzorij (lat. responsorium 'odgovor', hcsl. rešponb). ${ }^{28}$ Kao što je slučaj s antifonama, responzoriji se pojavljuju u svim časovima dana, a njihovi su tekstovi svojevrsni pjevani sažetci ili teološki naglasci psalma, (biblijskog, hagiografskog ili patrističkog) čitanja koje im prethodi. ${ }^{29}$

U istraživanoj službi časova svetkovine Rođenja Gospodinova, kao i u drugim službama, pisar ovoga brevijara unosi određenu zbrku u rubriciranju. Naime, između čitanja se u Noćnoj službi prema tradiciji rimskoga obreda očekuje naizmjenično redanje, u parovima, oznaka »rêšponь« i »beršs«. Za razliku od toga, pisar BrBer $_{2}$ na više mjesta takvih parova donosi dva puta uzastopno rubriku »beršb « $\mathrm{s}$ tekstom retka (nasuprot očekivanju da druga rubrika u takvom paru bude »rêšponь «). U Jutarnjoj se službi pojavljuje naznaka »beršb«, ali nema zasebne najave za otpjev, tj. »rêšponь«. U manjim se časovima takvih pojava i omaški u rubriciranju nema.

${ }^{26}$ Terminološka napomena: prijevod evanđeoskog hvalospjeva Magnificat (Lk 1,46-55) u crkvenoslavenskom je jeziku veličitb. Antifona na f. 33d: danasb hrstb rodi se danasb spasitelb êvi se · danasb na zemli poûtb anjeli $\cdot i$ veselet'se ar'hanjeli d danas raduûtb se vsi pravadni rekuce · slava va vi'šnihı bogu aleluê $\cdot N a$ latinskom jeziku, u Breviarium Romanum 2012 (liturgijski element 899) nalazi se identična antifona: Hodie Christus natus est: hodie saluator apparuit: hodie in terra canut angeli, laetatur archageli: hodie exultant iusti, dicentes, Gloria in excelsis Deo, alleluia.

${ }^{27}$ Vers je tematski i sadržajno neodvojiv od ostatka responzorija (HUGHES 2004: 26-30; PINELL 1996: 116-117).

${ }^{28}$ U Noćnoj službi časova responzorij dolazi nakon svakog čitanja, praćen versom. U Jutarnjoj i Večernjoj službi časova vers prethodi responzoriju. U manjim časovima, versi i responzoriji redaju se tako da se najprije otpjeva responozorij, a zbor odgovara s dva versa.

${ }^{29}$ O responzorijima i načinu pjevanja službe časova vidi TAFT 993: 134-138. U tradiciji se rimskoga obreda responzoriji dijele na: responsoria prolixa (dugi responzoriji) koji dolaze u Noćnoj službi i responsoriola (kratki responzoriji) koji slijede kratka čitanja u manjim časovima. Responzoriji se mogu dijeliti na psalamske responzorije, responzorije koji proizlaze iz čitanja i povijesne responzorije (RIGHETTI 1969: 773). 
Na nekim mjestima, kao u primjeru iz Večernje službe uoči svetkovine Rođenja Gospodnjega koji slijedi, pisar spaja beršb i antifonu. Naime, u latinskoj je tradiciji, primjerice u Breviarium Romanum 2012 (liturgijski element 839), kao i u starijim brevijarima donesen ovakav vers:

\section{Crestina die delebitur iniquitas terrae. \\ R. Et regnabit super nos saluator mundi. ${ }^{30}$}

Pisar $\mathrm{BrBer}_{2}$ na analognom mjestu spaja vers i antifonu:

beršb $\cdot \hat{u} t r e ̂ s ' n i \cdot$ d'nb zagladit se bezakonie zemle $\cdot i$ cêsarstvovati vačnetb nad'nami . beršb · egda vzaš'lo budet'sln'ce ot nebese uzrit' estb cêsarb cêsaremb · ishode ot matere lêki ženihb ot ložnice svoee ${ }^{31}$

Ovakve omaške nisu rijetkost u prepisivanju brevijara. Slična se omaška nalazi i u Pašmanskom brevijaru na f. 25a, što upućuje da su pisari i priređivači brevijara pojedine liturgijske elemente prepisivali vjerojatno iz starije matice. Ovom prilikom nisu detaljnije istraživane starina i tradicija pjevanih elemenata brevijara, antifona i responzorija, iako ta pitanja itekako zavrjeđuju znanstvenu pozornost jer mogu pomoći utvrditi matice iz koje se prevodilo ili prepisivalo brevijare. Neka bude dometnuto da su antifone i responzoriji iz hrvatskoglagoljskih brevijara vrijedan izvor najstarije hrvatske liturgijske lirike te da zasada nisu muzikološki istraženi.

Pored pjevanih elemenata i psaltira, služba časova rimskoga obreda obiluje dužim i kraćim svetopisamskim, patrističkim i hagiografskim čitanjima, koja se pojavljuju u određenom rasporedu. ${ }^{32}$ Time zapravo brevijar sadržajno objedinjuje nekoliko različitih liturgijskih knjiga: lekcionar, evanđelistar, homilijar te martirologij. ${ }^{33}$ Dužina lekcija u hrvatskoglagoljskoj liturgijskoj tradiciji ovisila je o priređivaču i prepisivaču liturgijskoga kodeksa, ${ }^{34} \mathrm{~s} \mathrm{time}$ da se uvijek čuvala razlika između duljeg, cjelovitog čitanja (lat. lectio) u Noćnoj službi i kratkih čitanja (lat. capitulum ili lectio brevis) u službi časova Jutarnje, Večernje i malih časova.

${ }^{30}$ Isti tekst donosi Breviarium de Camera f. 143 (20v).

${ }^{31} \mathrm{BrBer}_{2}$, f. 26d. U latinskom tekstu antifona glasi: Cum ortus fuerit sol de caelo, uidebitis rege regnum procedente a patre, taqua sposum de thalamo suo. Breviarium Romanum 2012, liturgijski element 840; Breviarium de Camera f. 143 (20v).

32 Više o čitanjima vidi RIGHETTI 1969: 751-769.

${ }^{33}$ Takve hagiografske cjeline su pasionali, martirologiji i životopisi svetaca. Usp. RIGHETTI 1969: 764-766.

${ }^{34} \mathrm{Za}$ recentnije iscrpne analize lekcija vidi STANKOVSKA 2015; BADURINA-STIPČEVIĆ 2009. 
U sadržaju BrBer ${ }_{2}$ nalaze se duža i kraća čitanja, prema redu službe časova, ali i nekoliko posebnosti. Lekcije u Noćnoj službi dolaze bez naziva svetopisamske knjige iz koje su prenesene. Pisar na više mjesta samo navodi rubriku čtenie, ili samo čti, čti pravo, čteniê, ili $v$ proste dni čt $\check{c ̌ t e n a}^{35} \mathrm{Na}$ nekim mjestima, poput f. 182a navodi pisar: kladutb se knigi kanoničaske $i$ čtut'se daže do v'znesenie..$^{36}$ Naslove svetopisamskih knjiga navodi rijetko, na primjer na f. 209a: poč'nut' knige cêsarske druge, ali pojedina duža čitanja iz svetopisamskih knjiga opširnije najavljuje. Tako u primjeru na f. 252a pisar navodi počni $\cdot b \cdot(=2)$ knige mahabeiske, te donosi tekst koji je pisan u slijedu, ali napominje $v$ proste dni razdilae (f. 252d). U drugom tjednu poslije Uskrsa čitaju se odlomci Knjige Otkrivenja, npr. f. 196c: Pokladaût'se knigi apokalipsie blaženago ivana apustola i čtu se $\cdot d i \cdot(=15) d n i$, te time započinje u slijedu tekst odlomaka iz Knjige Otkrivenja od f. 171b do 179d. Slično, za čitanje odlomaka iz proročkih knjiga navodi na f. 258a: pokladaût'se knigi $\cdot b \ddot{i} \cdot(=12)$ prorokovb, te donosi tekstove iz proročkih knjiga navodeći imena proroka.

Kada se u $\mathrm{BrBer}_{2}$ treba naći čitanje iz evanđelja koje je identično čitanju u misalima, pisar navodi samo incipit tog čitanja, potom kojem evanđelju tekst pripada te završava upisujući »i pročaê«. Tako u trećoj noćnici navodi čtenie svetago evanjeliê po lucê, matêu, mar'ku, ivanê ili samo po ivanê.

Homiletski i patristički tekstovi sadržani su u drugoj i trećoj noćnici, kao 4., 5. i 6. čitanje, odnosno 8. i 9. čitanje. BrBer $_{2}$ obiluje patrističkim i homiletskim tekstovima koji su doneseni kao duža čitanja, te predstavljaju izvor za istraživanje hrvatskoglagoljske patrističke literature i povijesti teologije. U prijevod s latinskog na hrvatski crkvenoslavenski jezik pisar $\mathrm{BrBer}_{2}$ unosi naslove kategorija tekstova ovako:

\begin{tabular}{|l|l|l|}
\hline hrvatski crkvenoslavenski & latinski & suvremeni hrvatski \\
\hline slovo & sermo & propovijed \\
\hline omilia & homilia & homilija \\
\hline ot iz'netie & ex tractatu & izlaganje \\
\hline
\end{tabular}

${ }^{35}$ O značenju izraza čti pravo, vidi RADOŠEVIĆ; DÜRRIGL 2020.

${ }^{36} \mathrm{U}$ primjeru rubrika na f. $237 \mathrm{c}-238 \mathrm{~b}$ pisar navodi koje se svetopisamske knjige čitaju u mjesecu rujnu. 
U sanktoralu, tj. drugome svesku BrBer ${ }_{2}$, druga noćnica (npr. na f. 10b-11c) sadrži hagiografska čitanja pojedinih svetaca, pri čemu pisar ne navodi izvor hagiografskoga teksta koji prevodi ili prepisuje.

Kraća čitanja u $\mathrm{BrBer}_{2}$ nalaze se nakon slijeda psalama s antifonama u službi časova Jutarnje, nakon slijeda psalama s antifonama u manjim časovima te nakon slijeda psalama s antifonama u službi časova Večernje. Pisar navodi u rubrici naslov kapitulb i potom donosi cijeli kapitul ili, ponegdje, samo njegov incipit. ${ }^{37}$

\subsection{Molitve, himni i ostali elementi službe časova}

Iako je čitava služba časova određena kao molitva hvale Bogu, pojedini časovi dodatno završavaju kratkim zaključnim molitvama, tzv. Collecta, kojima je svrha da teološki sažetim jezikom sintetiziraju i zaključuju određeni čas, a u latinskom se rimskome brevijaru takve molitve pojavljuju s naslovom Oratio. ${ }^{38}$ $\mathrm{U} \mathrm{BrBer}_{2}$ se u oba sveska one nazivaju oraciê, ili na nekim mjestima ograciê, ogracionb. U temporalu BrBer $_{2}$ je 164, a u sanktoralu 117 zaključnih molitava.

Uz zaključne molitve, u tradiciji rimskoga obreda, nakon Jutarnje i Večernje službe časova molile su se komemorativne ili zagovorne molitve (lat. Commemorationes $)^{39} \mathrm{u}$ čast svetih apostola Petra i Pavla, svetoga Križa te za mir. Molitvama je prethodila antifona s psalmom $130 \mathrm{u}$ Jutarnjoj ili psalmom 51 u Večernjoj službi. Tako je pisar BrBer $_{2}$ u svoj tekst unosio molitve na mjestima na kojima su trebale biti pjevane ili čitane, ali i rubrikama u kojima je dodatno pojašnjavao kada se sve one trebaju moliti. Primjerice, na f. 68c nalazi se molitva od dana (subota u osmini Bogojavljenja), potom slijedi molitva sv. Petru apostolu ${ }^{40}$ i na f. $68 \mathrm{~d}$ molitva za mir. ${ }^{41}$ Rubrika na f. $68 \mathrm{~d}$ objašnjava

${ }^{37} \mathrm{U}$ tradiciji molitve časova, posebno benediktinske, kapituli su bili odlomci koji se nisu čitali iz kodeksa, nego ex corde. Usp. RIGHETTI 1969: 767.

${ }^{38}$ Više o kratkim molitvama u službi časova i njihovoj tradiciji vidi PINELL 1996: 158-166; RIGHETTI 1969: 787. Takve molitve kojima se zaključuje određeni čas, nosile su teološku tematiku liturgijskog vremena ili slavlja određenog sveca. Koncipirane su prema latinskom rimskom običaju te sastavljene kao kratke i sažete rečenice s trima sastavnim dijelovima: invokacijom, peticijom i doksologijom.

${ }^{39}$ Usp. RIGHETTI 1969: 788.

${ }^{40}$ bože egože desnica blaženago petra apustola hodeça va v'lınahb mor'skihb da ne pogreza bi vzdviže $\cdot$ i takoe apustola pavla tri kratb utapaûciê ot glubini mora izbavi ni $\cdot$ usliši nasb milostivb i podai da oboû vêc'nuû slavu da n'slêduemb · hrbstomb gospodemb.

${ }^{41}$ bože ot negože svêta želêniê rês'ni svêtb i prava sutb dela dai rabomb i rabinbmb tvoimb ons mirb egože v'ś mirb ne možetb dati · i da sr'ca naša tvoimb zapovedemb podbdana · i otvrg' 
da više rečeni antifoni i oracie glagolût se na v'sehb vêčernihb sobotb i na ûtrnahb 'nedêlnihb i vếr 'ni ot see nedêle do nedilê do nedile cvit'ne i ot oktabi petikostb do prišastva razvi svetacb duplihb $\cdot i$ oktabb ihb. Slično se na f. 76c donosi molitva u čast sv. Križa, ${ }^{42}$ a odmah nakon toga se u rubrici navodi da se nastavi molitvom u čast sv. Petra apostola i molitvom za mir.

Molitva u četvrtak, 4. tjedna korizme posebna je u hrvatskoglagoljskoj i latinskoj liturgijskoj tradiciji. Naime, u slijedu euhologija korizme, pisar donosi zaključnu molitvu Jutarnje službe časova u čast sv. Kuzmi i Damjanu: da v'zvelitčit' te gospodi svetiû tvoiû kuz'mi i dom'êna blaženi praz'nikb (f. 120b). U latinskom brevijaru identična je molitva: Magnificet te domine sanctorum tuorum Cosmae et Damiani beata sollemnitas. ${ }^{43}$ Naime, na taj dan je određena stacionalna misa u rimskoj bazilici sv. Kuzme i Damjana, te je molitva u službu časova Jutarnje prenesena iz misala. ${ }^{44}$

Osim zaključnih i zagovornih molitava u službi časova, u sadržaju se nalaze i drugi molitveni obrasci, poput kratkih zaziva koji su u formi versa otvarali i zatvarali molitveni čas. U latinskoj tradiciji Pozivnik (lat. invitatorium) prije Noćne službe počinjao je versom Domine, labia mea aperies, a u hrvatskoglagoljskim brevijarima ustnê moi otvrzaeši, koji se u BrBer ${ }_{2}$ nalazi zapisan samo jednom, na f. 56a temporala. ${ }^{45}$ Versom Deus in adjutorium započinjali su svi časovi u rimskom obredu, a u hrvatskoglagoljskoj tradiciji to je prevedeno bože v pomoĉb moû van'mi Svi su navedeni zazivi završavani molitvom Slava otcu (lat. Gloria Patris).

Zazivi Kyrie i Christe eleison ${ }^{46}$ u službi časova molili su se na kraju Jutarnje i Večernje službe časova te nakon Prvoga časa, a iza tih zaziva slijedio je niz molitava za pojedine nakane (lat. preces) ${ }^{47} \mathrm{U} \mathrm{BrBer}_{2}$ su naznačena mjesta na kojima se mole te molitve, a nakon kojih je slijedila molitva Gospodnja, Oče naš. Neka se spomene i da je u rubrici na f. $76 \mathrm{~b}$ pisar unio rubriku: $n a-$ viĉamo da na matutini i na vičerni · otbče našb glagolet se nikoliko visoko · a na pročihb godinah'šaptomb · i tako vidimo budi da v prostê dani po vsa

otêta užas'ti budite tvoimb zaĉiĉeniemb tih' gospodemb našimb.

${ }^{42}$ vêč'nimb nebesb molimb te gospodi miromb shrani $\cdot$ eže d'revomb svetago križa tvoego nasb iskupiti nbsb račilb esi $\cdot$ iže s' tobô̂.

${ }^{43}$ Breviarium Romanum 2012, liturgijski element 1994.

${ }^{44}$ Za molitvu u čast sv. Kuzmi i Damjanu na latinskom jeziku u misalu vidi LIPPE 1899: 92.

${ }^{45}$ Za povijest i tradiciju zaziva vidi RIGHETTI 1969: 789-780.

${ }^{46} \mathrm{U}$ prijevodu na hrvatski crkvenoslavenski jezik: gospodi pomilui $\cdot$ hrbste pomilui $\cdot$ gospodi pomilui (npr. BrBer ${ }_{2}$ f. 5b).

${ }^{47}$ Usp. RIGHETTI 1969: 785 
vrimena eg'da pridetb ka otčenašu eže prije berši glagolûtb se ot vsehb s' prekloneniems kolêni. Tradicija da se molitva Gospodnja moli tiho potječe iz ranosrednjovjekovne službe časova gdje se ona molila sub silentio, osim zadnjeg zaziva Et ne nos inducas in tenetationem, sed libera nos a malo. ${ }^{48}$ Sam tekst molitve Gospodnje, otbče našb, ne nalazi se u BrBer ${ }_{2}$, nego samo napomena u rubrici. Također, u brevijaru nema ni teksta molitve zdrava marie, koja se molila na početku Matutina, Prvoga časa i Večernje službe časova.

Uz navedene molitve, na početku Matutina, Prvoga časa i u Povečerju molilo se Vjerovanje čiji je cjelovit tekst pisar donio u sadržaju Povečerja (kum 'plêtu) na f. 69c, dok u rubrikama na drugim mjestima samo navodi $r c i$ - vêruû.

Vrijednu tekstualnu cjelinu u BrBer ${ }_{2}$ čine tekstovi himana. Himan, kao poetski tekst, u službi časova rimskoga obreda, dolazi nakon cjeline psalama s antifonama, a prije molitve jer je njegova tematika određena molitvom. ${ }^{49} \mathrm{U}$ BrBer $_{2}$, temporal sadrži 72 himna, a sanktoral 40. Neke je tekstove himana pisar $\mathrm{BrBer}_{2}$ donio samo u incipitu jer se ponavljaju, a u sanktoralu upućuje na himan koji se nalazi u komunalu. Himan Te Deum laudamus, koji se pjeva nakon posljednjeg čitanja u Noćnoj službi, pisar BrBer ${ }_{2}$ ne donosi u cijelosti, već samo napominje u rubrikama tebe bože hvalimb. Isto tako i himan Gloria in excelsis Deo, koji ne pripada službi časova, nego samo onim službama časova koje prethode misi, poput prve mise na Rođenje Gospodinovo i na nedjelje. ${ }^{50}$

\subsection{Druge posebnosti BrBer $_{2}$ i napomene za daljnja istraživanja}

$\mathrm{BrBer}_{2}$, kao i ostali hrvatskoglagoljski rukopisi, ima još neke posebnosti koje je vrijedno zapaziti, pogotovo kada se istražuje njihov liturgijsko-povijesni kontekst. Među najočitijima je hrvatskocrkvenoslavensko nazivlje liturgijskih elemenata brevijara. Pisar BrBer $_{2}$ nastojao se držati nazivlja koje je već postojalo u hrvatskoglagoljskoj liturgijskoj tradiciji. Tako navodi naslove časova: ûtrna, matutinê, $k$ primê, ter'cê, šek'stê, nonê, vrêmenihb dnevnihb, $k$ godinamb, večer'na, kum 'plêta. U prijevodu s latinskog jezika, pisar je sustavno (i pogrešno) Noćnu službu (lat. matutinum) nazivao ûtrna, a Jutarnju službu (lat. laudes) matutinê. Drugih terminoloških posebnosti nema, ali je vrijedno za povijest liturgije na hrvatskom jeziku zabilježiti navedene nazivke

\footnotetext{
${ }^{48}$ Usp. RIGHETTI 1989: 786

${ }^{49}$ Usp. PINELL 1996: 153-154.

${ }^{50}$ Rubrika na f. 263d opisuje kada se govori slava va viš'nih'bogu.
} 
koji su postavili temelje hrvatske crkvenoslavenske, ali i hrvatske suvremene liturgijske terminologije.

Zahvaljujući suvremenim tiskanim i digitalnim ${ }^{51}$ izdanjima transliteracije tekst hrvatskoglagoljskog brevijara postao je dostupan istraživačima teološke i liturgijske grane znanosti. U sadržaju hrvatskoglagoljskih brevijara ostaje još znanstvenih interesa, posebno iz područja liturgijske tekstologije i istraživanja euholoških elemenata, himana i patrističkih tekstova, a što do sada nije učinjeno sa strane teološke ili liturgijske analize. Osim tekstoloških istraživanja, istraživanje pjevanih dijelova službe časova, posebno prijevoda himana, daju daljnju perspektivu u istraživanju načina glagoljskog pjevanja u liturgiji.

Liturgijsko tekstološko istraživanje hrvatskoglagoljskih brevijara otvara perspektivu stvaranja stematologije hrvatskoglagoljskih liturgijskih rukopisa, jer pored jezičnih posebnosti, tekstovi brevijara kriju i tekstološke posebnosti te mogu biti put ukazivanju na maticu iz koje su prepisani ili maticu na latinskom jeziku iz koje su prevedeni hrvatskoglagoljski liturgijskih tekstovi.

\section{ZAKLJUČAK}

Ovim je istraživanjem potvrđena pretpostavka da se struktura $\mathrm{BrBer}_{2}$, kao i drugih hrvatskoglagoljskih brevijara "po zakonu rim'skago dvora«, doista podudara s latinskim brevijarima rimskoga obreda ( $\mathrm{tj}$. brevijarima secundum consuetudinem (ili morem) Romanae Curiae). Ti su latinski brevijari od sredine 13. stoljeća rašireni po čitavoj Europi, dospjeli i do naših krajeva gdje su od sredine 14. stoljeća do Tridentskoga sabora, između ostaloga, bili predlošci za prevođenje i priređivanje hrvatskoglagoljskih brevijara. Analiza strukture sadržaja ukazala je na postojanje svih elemenata prisutnih u latinskim brevijarima rimskoga obrada, ali i na njegove posebnosti u smislu pisarskih pogrešaka.

BrBer $_{2}$ jedan je od rijetkih brevijara koji je uvezan u dva sveska: prvi sadrži temporal, drugi sanktoral. Očito je da nedostaje treći svezak koji sadrži komunal, a osim njega nedostaju pripadajući psaltir i kalendar, koji su bili sastavni dio svakoga brevijara. Također, brevijar ne sadrži notne zapise, ali sadrži tekstove pjevanih dijelova službe časova.

Kalendar $\mathrm{BrBer}_{2}$ se mogao nalaziti u svesku komunala, a moguće ga je i rekonstruirati na temelju sanktorala, budući da je on sačuvan u cijelosti. Či-

${ }^{51}$ Posebno je vrijedno upozoriti na platformu beram.stin.hr na kojoj se nalazi transliteracija obaju svezaka $\mathrm{BrBer}_{2}$. 
njenica da nedostaje psaltir, a postoje rubrikalne upute iĉi v'saltire upućuje na tri mogućnosti: 1. psaltir se nalazio u pretpostavljenom trećem svesku, 2. uz BrBer $_{2}$ se koristio neki drugi kodeks s tekstovima psalama, 3. pisar je priređivao brevijar za nekog klerika koji je psalme znao naizust.

Pjevani dijelovi i glagoljaško liturgijsko pjevanje uopće ostali su izvan ovoga istraživanja, ponajprije stoga što se ono prepušta muzikolozima i drugim istraživačima povijesti liturgije. Budući da su za to potrebne posebne studije, ostavljena su otvorena i pitanja teološko-tekstološke analize euholoških elemenata, himana, responzorija i antifona, koji sadrže vjerojatno najstariju hrvatsku teološku terminologiju, prevođenje latinske metrike i sažetih semantičkih teoloških cjelinâ rimskoga obreda. Ostavljamo otvorenim i pitanje latinskog predloška $\mathrm{BrBer}_{2}$, na koje možemo samo dati napomenu: kao što ne postoje dva ista hrvatskoglagoljska brevijara, tako ne postoje ni dva ista latinska brevijara, te je potragu za latinskim predloškom moguće tražiti prema tipologiji i prema kontaktnom području hrvatskoglagoljske liturgijske tradicije s latinskom liturgijskom tradicijom, a to je područje rasprostranjeno od južne Dalmacije - pa sve do Rima.

\section{IZVORI}

BrBer $_{2}=$ Drugi beramski brevijar, 15. stoljeće, Ljubljana, NUK, sign. Ms 163.

Breviarium Romanum 2012 = Breviarium romanum ex Decreto Sacrosancti Concilii Tridentini restitutum. 1568., Romae. Edizione anastatica, Introduzione e Appendice a cura di Manlio Sodi - Achille Maria Triacca. Libreria Editrice Vaticana, 2012.

Breviarium de Camera = Breviarium de Camera secundum morem sanctae Romanae Ecclesiae (...) 1521. Bibliotheca Apostolica Vaticana, sign. Liturgia, C. Folio 12.

Breviarium antiquissimum $=$ https: $/ /$ www.e-codices.unifr.ch $/$ en $/$ sbe $/ 0083 / 8 \mathrm{v} / 0 /$ Sequence-971 (10. 7. 2020.)

$\mathrm{BrPm}=$ Pašmanski brevijar, 14.-15. stoljeće, Zagreb, HAZU, sign. III b 10. Izvori Staroslavenskog instituta - https://izvori.stin.hr (1.8. 2020.)

\section{LITERATURA}

BADURINA-STIPČEVIĆ, V. 2009. Knjige o Makabejcima u hrvatskoglagoljskoj književnosti. Druga knjiga o Makabejcima u hrvatskoglagoljskim brevijarima. Slovo 59: $1-57$. 
CATELLA, A. 1994. Modelli storici di riforma dell'»Officium Divinum«. Liturgia delle Ore. Tempo e rito. Roma: Edizioni liturgiche, 125-134.

CATELLA, A. 2012. La Liturgia delle Ore. Celebrare il mistero di Cristo. Vol. III. La celebrazione e i suoi linguaggi. Roma: Centro Liturgico Vincenziano, 257-321.

GAJDOŠ, V. J. 1996. Medicejský glagolský kódex. Slavia 35: 36-56.

GRABAR, B. 1984. Tiskani glagoljski Baromićev brevijar. Slovo 34: 159-180.

HUGHES, A. 2004. Medieval Manuscripts for Mass and Office. A Guide to their Organization and Terminology. Toronto: University of Toronto Press.

JAPUNDŽIĆ, M. 1955. Glagoljski brevijar iz g. 1465. (Vaticano - Slavo 19). Radovi Staroslavenskog instituta 2: 155-191.

KOŠĆAK, S. 2020. Teološko-alegorijsko tumačenje noćne službe oficija u liturgijskoj ekspoziciji Vilima Duranda (1230. - 1296.) s naglaskom na antifone i psalmodiju. Slovo 70: 23-46.

KUNZLER, M. 2003. La liturgia della Chiesa. Milano: Jaca book.

LIPPE, R. 1899. Missale Romanum Mediolani, 1474. Vol. I. Text. London: Henry Bradshaw Society.

MACROBERT, C. M. 2020. Observations on the Liturgical Psalter in Ms. Canon. liturg. 172 (Bodleian Library, Oxford). Slovo 70: 77-91.

MIHALJEVIĆ, M. (ur.) 2018. Drugi beramski brevijar. I. dio. Zagreb: Staroslavenski institut.

MIHALJEVIĆ, M. (ur.). 2019. Drugi beramski brevijar. II. dio. Zagreb: Staroslavenski institut.

PANTELIĆ, M. 1965. Glagoljski brevijar popa Mavra iz godine 1460. Slovo 15-16: 94 149.

PANTELIĆ, M. 1976. Kulturno-povijesni značaj hrvatskih glagoljskih kodeksa. Crkva u svijetu 11/3: 237-246.

PANTELIĆ, M. 1971. Odraz sredine u hrvatskoglagoljskim liturgijskim kodeksima 14. i 15. stoljeća. Slovo 21: 324-332.

PANTELIĆ, A. 1991-1993. Fragmenti hrvatskoglagoljskoga brevijara starije redakcije iz 13. stoljeća. Slovo 41-43: 61-146.

PINELL, J. 1996. Liturgia delle ore. Ana'mnesis, vol. 5. Genova: Marietti.

RADOŠEVIĆ, A.; M.-A. DÜRRIGL. 2020. Glagoljaška čitateljska zajednica na primjeru Drugoga beramskoga brevijara. Slovo 70: 191-216.

RIGHETTI, M. 1969. Storia Liturgica. Vol. II. L'anno liturgico. Il Breviario. Milano: Ancora Libri.

STANKOVSKA, P. 2008. Textová tradice a revize patristických breviářních textů. Slovo 58: 191-217.

STANKOVSKA, P. 2015. Odnos sadržaja homilija u Proprium de tempore sačuvanih hrvatskoglagoljskih i latinskih srednjovjekovnih brevijara. V. Badurina-Stipčević; S. Požar; F. Veličić (ur.). Hrvatsko glagoljaštvo u europskom okružju. Zagreb: Staroslavenski institut, 447-466.

STANKOVSKA, P. 2017. Některé faktory důležité pro posuzování slovní zásoby v chorvatskohlaholských breviáŕích. Filologija 68: 193-221. 
TAFT, R. 1984. Beyond East and West. Problems in Liturgical Understanding. Washington: The Pastoral Press, 151-164.

TAFT, R. 1993. The Liturgy of the Hours in East and West. The Origins of the Divine Office and its meaning for today. Second Revised Edition. Collegeville: The Liturgical Press.

TANDARIĆ, L. 1977. Hrvatskoglagoljski Padovanski brevijar. Slovo 27: 129-147.

TANDARIĆ. L. 1984. Hrvatskoglagoljski tiskani brevijar iz 1491. Slovo 34: 125-157.

\section{Summary \\ Kristijan KUHAR \\ ON THE CONTENT OF THE SECOND BERAM BREVIARY}

Croatian Glagolitic breviaries represent an extensive corpus of biblical and liturgical texts, whose texts were transmitted from the $13^{\text {th }}$ century until 1561, when the printed Brozic Breviary was published. Their investigation in the $20^{\text {th }}$ century produced valuable results from the perspective of language history, transmission of texts and their similarities, as well as palaeography. The Scientific Centre of Excellence for Croatian Glagolitism has enabled a new approach to researching Croatian Glagolitic breviaries, based on an analysis of their liturgical content.

This paper presents an overview of previous studies and their starting points for current and future liturgical research. The central part of the paper presents findings about the structure and content of the Second Beram Breviary, establishing criteria for researching other Croatian Glagolitic breviaries.

Key words: Glagolitism, breviary, Second Beram Breviary, liturgical history

Kristijan KUHAR

Old Church Slavonic Institute

Zagreb (Croatia)

kristijan.kuhar@stin.hr 